\title{
Clonal evolution in a patient with CML detected by FISH precedes imatinib treatment failure
}

Virginia Enriquez ${ }^{1}$, Judith Cruz ${ }^{1}$, Olga Gutierrez ${ }^{1}$, Maria Teresa Salles ${ }^{1}$, Pablo Vargas ${ }^{2}$, Arturo Martínez ${ }^{2}$, Myrna Candelaria ${ }^{1}$, Rafael Hurtado ${ }^{2}$ and Eduardo Cervera*1

Address: ${ }^{1}$ Instituto Nacional de Cancerología, México, D.F and ${ }^{2}$ Hospital Angeles del Pedregal, México, D.F

Email: Eduardo Cervera* - isabel.ec@gmail.com

* Corresponding author

from 24 $4^{\text {th }}$ Annual Meeting of the National Cancer Institute of Mexico

Mexico City, Mexico. 14-17 February 2007

Published: 5 February 2007

BMC Cancer 2007, 7(SuppI I):A4I doi:I0.I |86/I47I-2407-7-SI-A4I

This article is available from: http://www.biomedcentral.com/I47I-2407/7/SI/A4I

(C) 2007 Enriquez et al; licensee BioMed Central Ltd.

\section{Background}

Imatinib (IM) inhibits the TK protein from chromosome Philadelphia (Ph). However, less than $10 \%$ of IM-treated patients become resistant. Second generation TK inhibitors are on active clinical research aimed to overcome most, but not all, important mutations.

\section{Case report}

A 61 year-old male was diagnosed on Sep/98 with CML chronic phase, he was treated with hydroxiurea, interferon and Ara-C. On July/01 the patient was on complete hematological response (CHR), but $\mathrm{Ph}$ positive in karyotyping (Ky) and fluorescence in-situ hybridization (FISH), there were not additional abnormalities. Patient began IM treatment, $400 \mathrm{mg} /$ day. After 4 months of treatment, $+\operatorname{der}(22)$ was detected, but the patient was still on CHR. On subsequent visits, the patient had an increased frequency of chromosomal abnormalities, and after 2 years he lost CHR, regardless of the increase IM dose and the concomitant use of Ara-C. The patient was included on a dasatinib phase II protocol. 2 weeks after he had a profound cytopenia and 2 months after had CHR. Table 1 shows clinical and hematological and Ky and FISH follow-up.

\section{Conclusion}

Additional abnormalities found on Ky and FISH could preceed treatment failure. Molecular monitoring is required to guide treatment decisions. The role of second generation TK inhibitors needs to be defined. 
Table I: Clinical and hematological and Ky and FISH follow-up

\begin{tabular}{|c|c|c|c|c|}
\hline Sample & Date & Ky & FISH & Treatment \& clinical condition \\
\hline 1 & $\mathrm{Jul} / 0 \mathrm{I}$ & Only Ph & Only $\mathrm{Ph} 35 \%$ & Began IM 400 mg/d CHR \\
\hline 2 & Nov/0I & $\mathrm{Ph}$ plus double $\mathrm{Ph}$ & Not enough material & IM $400 \mathrm{mg} / \mathrm{d}$ CHR \\
\hline 3 & Jan/02 & No growth & Only Ph $26 \%$ & IM $400 \mathrm{mg} / \mathrm{d}$ CHR \\
\hline 4 & Sep/02 & Hipodiploid plus Ph & $\begin{array}{c}\text { Only } \mathrm{Ph} 22 \% \\
\text { Clone BCR amplified without } \mathrm{Ph} 3 \% \\
\text { Clone ABL amplified and } \mathrm{Ph} 5 \%\end{array}$ & IM 400 mg/d Leucocytosis \\
\hline 5 & Jun/03 & Only Ph & $\begin{array}{c}\text { Only } \mathrm{Ph}=28 \% \\
\text { Clone BCR amplified without } \mathrm{Ph}=1 \% \\
\text { Clone } \mathrm{ABL} \text { and/or } \mathrm{BCR} \text { amplified with } \mathrm{Ph}=28 \% \\
\text { Clone } \mathrm{ABL} \text { and/or } \mathrm{BCR} \text { amplified and double } \mathrm{Ph}=51 \% \\
\text { Clone } \mathrm{ABL} \text { and } \mathrm{BCR} \text { amplified with triple } \mathrm{Ph}=11 \% \\
\text { Clone } \mathrm{ABL} \text { lost with } \mathrm{Ph}=5 \%\end{array}$ & IM $600 \mathrm{mg} / \mathrm{d}$ \\
\hline 6 & Nov/03 & $\begin{array}{l}\text { Ph plus lost } \mathrm{Y} \text {, marker chromosome, trisomy chr 19, double } \\
\text { Ph and trisomy chr } 8 \text {. }\end{array}$ & $\begin{array}{c}\text { Only } \mathrm{Ph}=4 \% \\
\text { Clone } \mathrm{ABL} \text { amplified without } \mathrm{Ph}=1 \% \\
\text { Clone } \mathrm{ABL} \text { and/or } \mathrm{BCR} \text { amplified with } \mathrm{Ph}=18 \% \\
\text { Clone } \mathrm{ABL} \text { and/or } \mathrm{BCR} \text { amplified with double } \mathrm{Ph}=74 \% \\
\text { Clone } \mathrm{ABL} \text { and } \mathrm{BCR} \text { amplified with triple } \mathrm{PH}=1 \% \\
\text { Trisomy chr } 8=72 \%\end{array}$ & IM 600 mg + Ara-C \\
\hline 7 & $\mathrm{Jul} / 04$ & No growth & $\begin{array}{c}\text { Only } \mathrm{Ph}=44 \% \\
\text { Clone } \mathrm{ABL} \text { amplified with } \mathrm{Ph}=6 \% \\
\text { Clone } \mathrm{ABL} \text { and/or } \mathrm{BCR} \text { amplified with double } \mathrm{Ph}=17 \%\end{array}$ & IM $800 \mathrm{mg} / \mathrm{d}$ \\
\hline sample & Jan/ 05 & & & Began with dasatinib \\
\hline 8 & $\mathrm{Dec} / 05$ & No growth & Only $\mathrm{Ph}=18 \%$ & Dasatinib \\
\hline
\end{tabular}

